\title{
Access to social security for digital platform workers in Germany and in Russia: a comparative study
}

\author{
Olga Chesalina* \\ Ph.D. (Minsk), LL.M. (LMU), Senior Researcher \\ at the Max Planck Institute for Social Law and Social Policy, Munich
}

Recibido: 3.4 .2018

Aceptado: 24.5 .2018

DOI: https://doi.org/10.20318/sllerj.2018.4433

\begin{abstract}
A common feature of platform work in Germany and Russia is that in both countries the new forms of employment can usually only be classified as self-employed work in the form of 'solo self-employment', despite the fact that platforms use direct and indirect control mechanisms indicating a personal or at least an economic dependency of the digital workers on the platforms. The difference is that, in Germany, as the main rule, self-employed persons are not obligatorily insured in the state pesion insurance scheme, whereas in Russia, unlike Germany, the state pension insurance scheme is mandatory for all self-employed persons.

Considering the different legal frameworks in Germany and in Russia, the article analyses various reform proposals aiming at tackling the above-mentioned challenges for the social security systems, and looks for adequate responses to ensure access to social security for digital platform workers. In particular, the following questions are investigated: Is it sufficient to subsume digital work under the existing employment categories? Could it be an appropriate solution for the access of digital workers to social security to introduce a new employment category only in social law?
\end{abstract}

Keywords: digital platform worker, social security, self-employed person.

\section{Introduction}

Platform economy is characterized by crowdwork and work on demand via apps (De Stefano, 2016: p.1). From the legal point of view it is very important to distinguish between these two types of digital platform work. In the case of crowdwork, internal tasks are addressed to an indefinite and unknown large number of organisations or individuals via crowdworking platforms. This work is both managed and carried out online. It corresponds to non-manual work requiring digital skills. (Eurofound, 2015). In the case of work on demand via apps the execution of specific services, such as transport, cleaning and running errands etc. is offered to an indefinite number of individuals by means of electronic platforms (app companies) (De Stefano, 2016: p.1). This work is managed online and carried out offline, usually manual work, requiring task-specific skills. Recently, work on demand has spread into the retail and hospitality sector, including restaurants (Bhattarai, 2018).

Different legislative responses at national and international level are required depending on the respective kind of digital platform work. Particularly problematic is that companies, by means of digitization, can 'hire' people from all countries - including developing and emerging countries - at the lowest wages, without carrying any social obligations and without any transaction costs.

While the challenges of the platform economy for labour law are lively discussed and researched, there are, so far, only very few studies (see below) and publications (e.g. Preis \& Brose, 2017; Suárez,

*chesalina@mpisoc.mpg.de 
2017) on the challenges that the platform economy and the approaches to appropriate solutions constitute for the social security systems.

The questions on the social security of platform workers are a very young field of research dealt with in recent studies. It is necessary to get more information about the motivation of digital platform workers, and there is a lack of information on the share of migrants and refugees among the platform workers.

From the point of view of social law, the central challenges of the platform economy are the lack of social security for digital workers as well as the fiscal sustainability of the social security systems. The fiscal sustainability of the social security systems is endangered not only by insufficient social security for digital workers (especially in old age) which can increase state social assistance expenses. Digital work also favours the shadow economy and informal work; new groups of invisible workers emerge (De Stefano, 2016: p. 21).

Russia in Eastern Europe and Germany in Western Europe belong to the countries where platform work is widely spread. The difference is that, in Germany, as the main rule, self-employed persons are not obligatorily insured in the state pension insurance scheme, whereas in Russia, unlike Germany, the state pension insurance scheme is mandatory for the self-employed. Considering the different legal frameworks in Germany and in Russia, in this article various reform proposals, aiming at tackling the above-mentioned challenges for the social security systems shall be analysed. Based on this analysis, adequate responses are being searched for to ensure access to social security for digital platform workers. In particular, the following questions are investigated: Is it sufficient to subsume digital work under the existing employment categories? Could it be an appropriate solution for the access of digital workers to social security to introduce a new employment category only in social law?

\section{Situation in Germany}

\section{Statistical data}

At least three empirical studies have been carried out on social issues of platform crowdwork in Germany. Two studies deal with crowdwork in a narrow sense (Leimeister, Durward \& Zogaj, 2016 and Bertscheck, Ohnemus \& Viete, 2016), and one study covers both crowdwork and work on demand (Huws, Spencer, \& Joyce, 2016).

According to the trade union IG Metall about one million people in Germany are engaged in crowdwork (IG Metall, 2017). According to the study carried out by Leimeister et. al. in 2016, 67 per cent of the crowdworkers were registered on platforms in the last 12 months. However, studies have shown that in Germany, in most cases, crowdwork is only carried out as a secondary occupation in addition to a main occupation: 39 per cent of the interviewees were employed and 31 per cent were in a vocational training or study (Bertscheck, Ohnemus \& Viete, 2016).

\section{Legal framework}

In Germany, obligatory social insurance is traditionally linked to a dependent employment and does not cover self-employed persons. According to $\S 7$ sec. 1 sentence 1 of the Fourth Book of the Social Security Code ('SGB IV') employment is dependent work, in particular in an employment relationship. The existence of employment is indicated by the presence of activities carried out by direction and an integration into the work organization of the issuer of the directions (translation from: Lingemann, Steinau-Steinrück \& Mengel, 2016: p. 546). The German social law category 'employment' is broader than the labour law category 'employment relationship'.

The self-employed persons are subject to obligatory social insurance in the following situations:

- Homeworkers or other persons working in the place of their choice for another person or institution are subject to all branches of social insurance on condition that they have one 'client' 
(Auftraggeber) from whom they 'directly' receive assignments ( $\$ 12 \mathrm{sec} .2$ of the Fourth Book of the Social Code - SGB IV).

- Self-employed artists and writers are also subject to all branches of social insurance (Artists' Social Security Act - Künstlersozialversicherungsgesetz).

Furthermore all 'solo self-employed persons' are subject to obligatory pension insurance if they receive orders only from one client ( $\$ 2$ sent. 1 no. 9 of the Six Book of the Social Code - SGB VI) and in some other cases.

However, these requirements for the obligatory social or pension insurance are not met by digital workers, at least in most cases (Mecke, 2016; Brose, 2017). According to the current social law, crowdworkers and on-demand workers can only be subsumed as solo self-employed persons who can be insured within the social security scheme only voluntarily.

However, there are many characteristics that distinguish 'digital' self-employed (especially crowdworkers who fulfill 'microtasks' and workers on-demand in the service sector) from 'classical' self-employed workers. Some researchers demonstrate the elements of their personal and/or economic dependency from the platforms (Däubler, 2015: p.341), which is typical for an employment relationship. In particular, General Terms and Conditions of Business (GTCB) settled by the platform provide direct and indirect control and surveillance mechanisms, on which the crowdworkers have no influence. The control mechanisms used by the platform at all stages, from the registration on a platform to the evaluation of the work results, at least indicate an economic dependency (which is common for 'employee-like persons'): The platform decides who gets access to the platform and for whom access will be blocked. The prior check of qualifications as part of the registration process is comparable to a job application procedure.

In addition, the work processes (e.g. through screenshots, tracking of workflows, mouse activities, etc.) and the work results are controlled. Instead of instructions/directions and performance control, evaluation, rating and feedback systems are used. Furthermore, digital workers have no influence on the amount of remuneration, because it is unilaterally determined either by the client or the platform (Däubler, 2015: p. 340). The tendency that the control mechanisms partly replace classical directives of the employers (Weisungsrecht) is also observed in the field of homework and telework. In the decisions of the German Federal Social Court while interpreting whether there is an employment relationship or not, however, control mechanisms still do not play a decisive role (Greiner, 2016: p. 306).

In the case of digital work, similar to non-standard work, the risks are transferred from the platform/client ('employer') to the digital worker ('employee'). The German Federal Social Court, testing the existence of an employment relationship, refers to the question who in fact carries entrepreneurial risks. In some cases the result is that, in particular, precarious contract designs are rewarded with the exemption of mandatory social insurance law. However, this approach ignores that the weaker part of the contract relationship is even more in need for social protection when the entrepreneurial risks are shifted to him or her (Greiner, 2016: p. 308). The Federal Labour Court, however, makes no distinction between voluntarily and involuntarily borne risks (Waas, 2017: p. 260). I share the opinion that anyone who voluntarily bears such risks shall be qualified as a self-employed worker and persons who either do not bear such risks or do so involuntarily shall be qualified as employees (Waas, 2017: p. 260).

In some cases, the platform's general terms and conditions provide that the payment of the service/task is carried out according to the lottery principle in such a way that only the best result (job) will be paid. If the crowdworking platform is located outside Germany, the crowdworker, as a rule, cannot even rely on the German legal regulations concerning the GTCB (Däubler, 2015: p. 342).

If the crowdsourcer/crowdworking platform determines by what time the jobs must be executed (Selzer, 2015: p. 39; Kocher \& Hensel, 2016: p. 986), this indicates a personal dependency. The German Federal Labour Court has developed criteria indicating the existence of personal dependency as the core feature of an employment relationship. One of these criteria is that someone is not free to refuse tasks offered by his or her contractor. However, at the moment the German Federal Labour Court interprets these criteria in quite formal terms. For example, in its decision of 14 July 2016, the German Federal Labour Court (9 AZR 305/15) stated that showing that for the plaintiff it was 'practically unthinkable' to refuse tasks was not enough to prove personal dependency. The fear that no more tasks will be assigned 
once a job has been refused proves only economic dependency. Digital workers, especially workers on demand, like Uber drivers, would therefore probably not be considered as employees, because, formally, they can refuse orders. However, they may receive lower ratings and even no more orders/be excluded from the platform if they repeatedly do so.

An interesting approach in this context are the holdings of Austria's Supreme Administrative Court (VwGH) in its decision of 1 October 2015 (2015/08/0020): The existence of personal dependency and, accordingly, an employment relationship can be denied if the crowdworker can refuse a job proposal without any sanction and if he/she has been aware of this possibility/right (Bruckner \& Krammer, 2017: p. 278).

But even if the relationship between the platform and the crowdworker cannot be interpreted as an employment relationship, the control mechanisms used by the platform indicate at least an economic dependency (which is common for 'employee-like persons'). This expresses the 'need for social protection' comparable to that of employees (Selzer, 2015: p. 44-45), one of the criteria required for 'employee-like persons'. However, it is not common that digital workers receive orders only from one client, which, according to the current German legislation, is a necessary condition for the application of the provisions of the social pension insurance (SGB VI) to 'solo self-employed persons' ( $\$ 2$ sentence 1 no. 9 SGB VI). Furthermore, also the provisions according to which homeworkers ( $\$ 12 \mathrm{sec} .2 \mathrm{SGB}$ IV) are subject to all branches of social insurance, usually do not apply, because the requirement that the homeworker must receive assignments 'directly' from one client is not met. According to the study by Leimeister et. al., more than 33 per cent of the crowdworkers perform services for different platforms.

As shown above, current legislation and court decisions do not take into account new manifestations of personal/economic dependency and the need for social protection of 'digital workers'. Therefore it shall be examined which reforms/changes would be possible in current social and labour law in order to fulfil this task.

\section{Discussed social law reforms}

\subsection{Introduction of an intermediary employment category}

Some labour law scholars consider it necessary to create a new intermediate category for digital workers because the latter do not fit into the categories 'employee' and 'self-employed persons' (Harris \& Krueger, 2015; De Stefano, 2016: p. 19). According to Prof. Davidov, the introduction of a third (intermediate) group between employees and independent contractors could help to find the right balance between universalism and selectivity and protect workers who share only some of the characteristics of employees by bringing them into the scope of some labour and employment laws (Davidov, 2017: p. 8). Some German scholars also consider it advisable to introduce an intermediate category between employees and self-employed persons in social law in order to tackle new forms of dependency of digital work and guarantee a minimum social insurance protection for the persons concerned (Preis \& Brose, 2017: p. 49).

The problem is that even in cases in which national legislation provides for a third category in labour and in social law, this category would not necessarily cover the same persons in labour and in social law and guarantee them the same level of labour and social protection.

To quote an example from German law: German labour law knows the category of 'employeelike persons' who are granted a limited number of labour rights. These persons are predominantly homeworkers and commercial agents. German social law does not use the term 'employee-like persons', but includes some groups of economically dependent persons into social insurance, such as homeworkers and artists. Homeworkers and artists are insured like employees, meaning that they pay only a part of the contributions and get the same social insurance coverage as employees. Another group of economically dependent persons, the 'solo self-employed who receive orders only from one client', are only covered by the pension insurance scheme and have to pay the contributions themselves.

It seems that the level of social protection of homeworkers is higher and more significant than the level of protection of their labour rights. The example of homeworkers and artists in Germany shows that it is possible to disconnect social protection from the employee status and to guarantee an adequate level of social protection for these persons. 
At the same time, court decisions on platform workers have already shown that, if there is an independent intermediate category in labour law, platform workers are more often classified in this category than as employees, e.g. as workers in the United Kingdom (see Pimlico Plumbers Ltd v Smith [2017]; Aslam, Farrar and others v Uber BV [2016]). The experience of some countries (e. g. Italy) shows that the introduction of an intermediary category will rather contribute to the circumvention of the existing 'employee' category and become an obstacle for (digital) workers to achieve appropriate labour and social law protection (Cherry \& Aloisi, 2017: p. 675) than to tailor-made solutions and more precise regulations.

\subsection{General social security law}

The 71st German Jurists Forum (DJT) has demanded that only those digital workers who are economically independent should be considered as 'self-employed digital workers'. Further, a reversal of the burden of proof for the existence of an employment relationship was recommended in order to improve the protection of the crowdworkers. In addition, the 71st DJT has demanded to include selfemployed crowdworkers into the social security system (2017). However, the solutions proposed by the DJT are very far-reaching and not clear. For example, it remains open whether the term 'employee' should be extended or the economic dependency should only indicate the existence of a personal dependency. Related to the proposal on 'independent digital workers', it remains open whether the requirement of activity for only one client ( $\$ 2$ sent. 1 No. 9 SGB VI) should be abandoned or whether the digital workers should be treated like homeworkers (by extension of $\S 12 \mathrm{sec}$. 2 SGB IV). In the last case, the question arises who (apart from the digital worker) is obliged to pay social insurance contributions (e.g. the platform operator or its client).

For cases with no (or not enough) personal dependency but only economic dependency from the platform it could be considered to widen the scope of $\S 12$ para. 2 SGB IV (social insurance of independent homeworkers). The advantage of this solution would be that in this case the platform or the client are obliged to pay social insurance contributions in all branches of the social insurance. Not only in Germany (Krause, 2016: p. 106) scholars emphasize that the provisions related to homework should be modernized in order to cover the new forms of employment: "cognitive homework is hard to shoehorn into statutory definitions of industrial homework" (Finkin, 2016). According to my opinion it would be a possible solution to modify and widen the scope of homework in relation to crowdworkers. However, this solution does not fit workers on demand who provide traditional services such as transport or cleaning, because these services are beyond the scope of the Homework Act. Workers on demand are usually domestic workers. Also in Germany domestic work is frequently part of the "shadow economy". In Germany, no specific legislation exists for domestic work, but general labour law applies.

In relation to the payment of contributions, the regulations introduced in the French Labour Code in 2016 have to be mentioned, which are applicable to self-employed persons who have access to one or more platforms offering electronic networking for their professional activities (Art. L. 7341-1 to Art. L. 7342-6). Among other things, this chapter of the Labour Code stipulates that if a worker concludes (takes out) an insurance against accidents at work or joins the voluntary accident insurance, the platform refunds his payment of contributions within the limit set by decree. It has to be observed how the French regulation will work in practice and if this might be a solution also for other branches of social insurance.

Anyway, the practical realization of the platforms'/clients' obligation to pay social insurance contributions seems quite difficult: The crowdworker is not in direct relationship with the client and often does not know for whom he works. In addition, contributions from platforms/clients in times of globalization could lead to a withdrawal of crowdwork from countries which have provided such regulations, as the platforms/their clients are able to choose crowdworkers worldwide. It would be desirable to create the framework conditions for payment of social contributions at least on a European level.

\subsection{Pension insurance}

The replacement of traditional core workplaces/jobs due to automation and digitalization, in addition to the demographic change, endangers the future financial viability of the social security systems. In 
the Green Paper Work 4.0, the German Federal Ministry of Labour and Social Affairs raises the question as to how 'long-term strategies to secure the income base of the statutory pension system and the social insurance system as a whole might look like? How can - in the view of a changed labour world, new forms of work and a changed age structure the population - the contribution basis be kept at a sufficient level to finance an adequate level of social security?'

In relation to required reforms in the field of pension insurance the most radical solution, which was demanded by unions (German Trade Union Confederation - DGB; United Services - ver.di) and social associations (German social association - Sozialverband Deutschland) (BMAS 2016: p.178), would be the introduction of a compulsory social insurance for everyone, generating income by work (Erwerbstätigenversicherung). This conception is not new (Buchholz \& Wiegard, 2014) and is discussed now again in the context of digitalization (Tornau, 2016: p.26).

A further proposal made by trade unions (e.g., ver.di), politicians and scholars to preserve the pension level is to include digital workers along with solo self-employed workers in the compulsory statutory pension insurance scheme. In the White Paper Work 4.0 of the German Federal Ministry of Labour and Social Affairs this solution is given preference, arguing that with the inclusion in statutory pension insurance, self-employed persons will receive the same rights and obligations as all insured persons (BMAS, 2016: p. 173). The same solution is provided for in the German Government's coalition agreement (Koalitionsvertrag, 2018: p. 93).

The idea of including solo self-employed workers in the compulsory statutory pension insurance scheme is also not new (Waltermann, 2010 a; Waltermann, 2010 b). The 68th German Jurists Forum proposed already in 2010 to incorporate the solo self-employed into the compulsory statutory pension insurance scheme and open up the voluntary state-subsidised private old age pension ('Riester pension') to them (DJT, 2010). In particular, it was proposed to delete from $\S 2$ sentence 1 no. 9 b) SGB VI the requirement that solo self-employed workers shall only be covered by the compulsory statutory pension insurance if they work 'basically only for one client'.

However, digital self-employed workers differ significantly from each other in terms of income. The spread of the household income among digital self-employed workers is even greater than among the 'classical' self-employed (Leimeister, Durward \& Zogaj, 2016: p. 43). The study on the socioeconomic background and the motives of crowdworkers in Germany (Bertscheck, Ohnemus \& Viete, 2016) and the study 'Crowdworker in Germany' (Leimeister, Durward \& Zogaj, 2016) have shown that about 60 per cent of the crowdworkers are included in a private pension scheme. For digital workers who are already insured in a private pension scheme, the inclusion into the statutory pension insurance is not necessary.

The study by Leimeister has shown that more than 50 per cent of the digital workers who carry out mostly unskilled and low-skilled 'microtasks' (which proved to be particularly precarious) are not insured in a pension scheme at all. For such digital workers, inclusion in statutory pension insurance does not solve the problem of old-age poverty, as contributions paid out of a very low income would only lead to pension entitlements below the social welfare level. Therefore, if this group of low-income crowdworkers had to pay contributions to the compulsory pension insurance themselves, their precarious situation would only get worse.

It cannot be assumed that, by inclusion into statutory pension insurance, solo self-employed persons will have the same rights and obligations as all the other insured persons (employees) and pay the whole sum of the contributions themselves (Hanau, 2017: p. 215).

Another solution debated is to either introduce a professional pension fund for digital workers (Interview 2016; p. 26) or widen the scope of the Artists' Social Security Act. It is interesting that, according to the German Crowdsourcing Association e. V. and the artists' social security fund, crowdworkers are not yet included in the artists' social security fund (Bundestag 2014, p. 12). In practice, however, some self-employed persons who are writing texts for onlineshops, guides or blogs are covered by the social insurance scheme for artists (Ludwig, 2016). In my opinion, the fund makes no difference between self-employed journalists or artists and crowdworkers, but lumps them together.

The problem with the above mentioned solutions (introduction of a professional pension fund for digital workers, widening the scope of the Artists' Social Security Act, or inclusion of crowdworkers into the statutory pension insurance for self-employed persons) is that they already assume that digital 
workers are a homogeneous group outside of the scope of the existing labour law and the existing obligatory social insurance schemes.

\subsection{Unemployment insurance}

Another important issue is the effect of digitalization on unemployment insurance. In Germany, a person is entitled to unemployment benefits if he/she has been in an employment relationship for 12 months during the last 24 months ( $\$ 142$ of the Third Book of the Social Code - SGB III). Self-employed persons can contribute to the public unemployment insurance scheme if certain conditions are fulfilled: he/she must work at least 15 hours a week in their own business and must have contributed to the unemployment insurance scheme for at least 12 months within the past two years (§ 28 a SGB III). It has become more and more difficult to meet these requirements due to the 'technological unemployment' and due to the fact that the newly arising jobs in the platform economy are often not covered by social insurance. Interruptions in employment histories have become common. Furthermore, the requirement of a 12-month employment relationship during the previous 24 months (framework period) does not take into account that in times of the platform economy, transitions between dependent and independent work happen more often.

The Federal Labour Agency has proposed to extend the framework period from two to three years (BA, 2015: p. 20). Possibly one could think about the introduction of a 'shorter' waiting period (e.g. six months in the last 12 months) in exchange for a shorter period of unemployment benefits (e.g. six months instead of the regular period of 12 months).

Another approach to solve the problem of interruptions in employment biographies would be the transition from an unemployment insurance to a labour insurance (Arbeitsversicherung), which has been proposed and discussed for years and which is also planned in the White Book. Work 4.0 (BMAS, 2016: p. 114). Such a labour insurance would help to take into account the new patterns of work histories with mixed forms of employment and transitions between dependent and self-employed work.

\section{Situation in Russia}

\section{Statistical data}

Although until now no comprehensive statistical data on the total number of digital workers in Russia is available, the studies already carried out demonstrate that platform economy is growing rapidly: In 2016 the monthly active users (MAU) of Yandex. Taxi grew by $120 \%$, of Gett (another transport platform) by $85 \%$, and of Uber by $140 \%$ compared to 2015 (Balashova, Li \& Vovnjakova, 2017). The equivalent of TaskRabbit in Russia, YouDo, has over 70000 registered freelancers (in spring of 2013 there were about 1000 of them). This platform provides different services: courier services, home repair, trucking, web development, legal assistance, etc. 50\% of the digital workers registered on YouDo have a higher education; $45.3 \%$ of them are between 25 and 34 years old; $44 \%$ of the workers are additionally involved in a dependent employment. There are also platforms that specialised on one special kind of services, e.g. courier and delivery (Peshkariki.ru) or repair services (Remontnik.Ru) (Suvorova, 2016).

Crowdworkers (electronic freelancers) in Russia are often very well educated. The highest demand for freelancers is in the following areas: IT, marketing, promotion of goods and services, design, advertising, sales, recruitment, consulting, accounting, design and construction (Polorotov, 2017). The internet platform 'FL.ru' dominates the Russian-language Internet and is one of the largest freelance marketplaces in Europe and the world with more than 1.5 million registered users (Shevchuk \& Strebkov, 2017: p. 403).

\section{Legal framework und already implemented reforms}

Russian legislation knows no intermediate categories between employees and freelancers such as 'employee-like persons' or 'workers' (like in the UK). According to Art. 20 of the Labour Code of the 
Russian Federation (further - LC RF) an employee is a natural person who enters into labour relations with an employer. Contrary to Germany, where homeworkers are not per se employees (and in most cases self-employed), homeworkers in Russia are persons who enter into labour contracts to perform work at home, using materials, tools, and mechanisms issued by the employer or acquired by the homeworker at his own expense (Art. 310 LC RF). Separate chapters of the LC RF are devoted to the labour relations of homeworkers (chapter 49) and domestic workers (chapter 48). In 2013 a new chapter 49.1 on the particularities of the labour regulations of distant workers (teleworkers) was added to the LC RF. According to Art. 312.1 LC RF, distant work refers to labour which, pursuant to the labour contract, is performed outside the employer's premises, branch office, representative office, or at another site beyond the employer's control using informational and tele-communicational networks (including the Internet) for the interaction with the employer on issues related to work performance. This means that the Russian legislator distinguishes between homework (mainly physical, low-qualified or non-qualified work) and distant work (high-qualified intellectual work), though the special regulations for both groups are the same. Homeworkers and distant workers can, for example, be dismissed on grounds provided for by both the Labour Code and the labour contract (Lyutov \& Gerasimova, 2017: p. 584).

Although, according to Art. 312.1 LC RF, digital workers can in some cases be subsumed under distant workers, they are nearly always classified as self-employed persons (individual entrepreneurs). Unlike Germany, self-employed persons are, however, insured under the social security scheme and obliged to pay social insurance contributions to pension and health insurance (Art. 430, 431 of the Tax Code of the Russian Federation), where they have to pay the whole sum of their contributions themselves. On the contrary, in case of dependent employment in Russia the employer pays the whole sum of the contributions to social insurance (without the participation of the employees). In Russia there are no minimum income thresholds, from which on social insurance for self-employed persons becomes mandatory. Due to high social insurance contributions during the last six years, the number of registered individual entrepreneurs in Russia decreased by 8\% (Faljahov, 2016), while the number of the non-registered selfemployed persons increased. In 201615.4 million people were employed in the informal economy, what is equivalent to 21.2 per cent of the total number of employed people ${ }^{1}$ in Russia (Egorova 2017). The spreading of mobile, Internet and cloud technologies favours the increase of the economy's informal sector (Egorova, 2017) and the circumvention of the legal regulations (Drahokoupil \& Fabo, 2016).

Since 2015 the introduction of a new employment category 'freelancer' has been actively discussed in Russia. There were different proposals as to who should be covered by this new category und regarding the question as to how many taxes and social contributions have to be paid by 'freelancers'.

On 26 July 2017 the Civil Code of the Russian Federation was amended. According to the new item 1 of Art. 23 (citizen's entrepreneurial activity) a citizen shall have the right to engage in entrepreneurial activities without forming a legal entity from the moment of his state registration in the capacity of an individual entrepreneur, with the exception of the cases, listed in item 2 of Art. 23. The new item 2 of Art. 23 lists certain types of entrepreneurial activity, for which it may be provided for by law that citizens may perform such activities without state registration as individual entrepreneurs. Before this amendment was made, it was not allowed to engage in business activities without state registration.

Since 1 January 2017, certain cases were established in item 70 of Art. 217 of the Second Part of the Tax Code according to which a 'freelancer' can provide services with regard to personal, domestic and (or) other similar needs without state registration as an individual entrepreneur: tutoring; cleaning, housekeeping, services concerning supervision and care of children, of sick persons, persons who have reached the age of 80 years, as well as other persons in need of constant external care according to the decision of a medical organization. For these freelancers 'tax holidays' have been introduced for two years, which means that their income of the years 2017 and 2018 is exempt from taxation, if they have been enrolled by tax authorities.

The effectiveness of such regulations raises great doubts. On the one hand, since there is no legal obligation for freelancers to enrol with tax authorities, most individuals have no incentives to do it

${ }^{1}$ The majority of them are not self-employed persons working in the informal sector but employed persons without a labour contract. 
voluntarily and pay taxes as of 2019. On the other hand, the new regulations favour the conclusion of civil-law contracts with domestic workers (including some categories of workers on demand) instead of labour contracts. Such regulations do therefore not contribute to the social protection of digital workers.

\section{Conclusion}

Recently, different solutions have been discussed in order to guarantee access to social security for digital platform workers. Some of the social security problems of digital platform workers are oldfashioned problems of social security of solo self-employed persons and false self-employed persons. Earlier reform proposals concerning these groups have now anew been discussed in the context of platform work.

Digital platform workers cannot a priori be classified as employees or self-employed persons or bogus self-employed persons or homeworkers or domestic workers, because the correct classification in each case depends on the nature of the activity (inclusive of whether the work is carried out online or offline) as well as on the design of the relationship between the digital work the platform and the client. Digital platform work does not constitute an independent form of employment. There seems to be no one-fits-all-solution to guarantee access to social security for digital workers.

Adequate responses for an access to social security for digital platform workers (except for those who are really self-employed) should have the objective to guarantee a minimum level of protection to digital workers and simultaneously find a person (depending on the type of platform work - a platform provider or requester/client) who is responsible for the payment of their social security contributions. This obligation is justified by the new forms of dependency caused by platform work.

It is not sufficient to include platform workers in the compulsory statutory social insurance scheme. The Russian experience, where the self-employed are obligatorily insured in the social security scheme and obliged to pay social insurance contributions to both pension and health insurance themselves, has shown that such regulations only favour the shadow economy and may prove futile, especially in countries where the level of guaranteed social protection is very low and where there is no regulatory stability. Also from the German perspective the inclusion of digital workers into social/pension insurance risks a worsening of the situation of the self-employed digital workers with a low income if the contributions has to be paid out of these low incomes, while, on the other hand, their chances to receive a pension above the social welfare level are low.

The German example of homeworkers and artists shows that realising access to social security is also possible only via social law reforms by disconnecting the social protection from the labour employment status. At the same time, a new third category would not necessarily cover the same persons under labour and social law and guarantee them the same level of labour and social protection. Furthermore, instead of tailor-made solutions and more precise regulations, an introduction of a third category might lead to the erosion of the 'employee' category and to the diminution of labour and social protection.

Notwithstanding the above, any national legal solution reaches its limits when platform operators or their clients are based abroad. It would therefore be desirable to create framework conditions for the payment of social contributions at least at the European level. The European Commission has launched a Proposal for a Council Recommendation on access to social protection for workers and the self-employed (European Commission, 2018). The wording of the Proposal for the Recommendation reveals two goals: first, to close formal coverage gaps and ensure adequate effective coverage of the self-employed; and second, to ensure the social and especially the economic sustainability of national protection systems.

I consider positive the goal of the proposed Recommendation to ensure for all workers and the self-employed formal and effective coverage of social protection and transparence of social protection entitlements. However, the EU soft law instruments cannot force member states to change the organisation of their social security schemes.

The next problem is that the proposed Recommendation does not really address the new challenges connected with platform economy, and especially the challenges faced by misclassification and circum- 
vention of legal regulations through platforms. The proposed Recommendation lays down the criteria for 'worker' status, meaning a natural person who for a certain period of time performs services for and under the direction of another person in return for remuneration. A definition for the term 'self-employed person' is not included in the proposal. Even if the criterion 'for and under the direction of another person' is the main feature of an employment relationship, this criterion in such abstract form does not take into account new manifestations of personal dependency of persons working for digital platforms.

\section{Reference List}

BA (Bundesagentur für Arbeit) (2015) Weißbuch 'Arbeiten 4.0' - Antworten der Bundesagentur für Arbeit auf die Herausforderungen der Digitalisierung. Available from: https://www.arbeitenviernull. de/fileadmin/Futurale/Statements/PDFs/BA.pdf [Accessed 22 October 2017].

BAG (Bundesarbeitsgericht) (2016) Urteil vom 14.06.2016 - 9 AZR 305/15. Neue Zeitschrift für Arbeitsrecht, 1453-1458.

Balashova, A.; Li, I. \& Vovnjakova, A. (2017) Uber took over Gett in terms of daily traffic in Russia. Available from: http://www.rbc.ru/technology and media/07/03/2017/58becbcd9a79475c283d8 $84 \mathrm{f}$.

Bertscheck, I. Ohnemus J. \& Viete S. (2016) Befragung zum sozioökonomischen Hintergrund und zu den Motiven von Crowdworkern. Bundesministerium für Arbeit und Soziales. Forschungsbericht 462. Available from: http://www.bmas.de/SharedDocs/Downloads/DE/PDF-Publikationen/ Forschungsberichte/fb-462-endbericht-crowdworker.pdf?_blob=publicationFile \&v $=4 \quad$ [Accessed 21 October 2017].

Bhattarai, A. (2018) Now hiring, for a one-day job: the gig economy hits retail. The Washington Post. Available from: https://www.washingtonpost.com/business/economy/now-hiring-for-a-one-dayjob-the-gig-economy-hits-retail/2018/05/04/2bebdd3c-4257-11e8-ad8f-27a8c409298b_story. html?noredirect $=$ on\&utm_term $=$. ae13e2683bd 7 .

BMAS (Bundesministerium für Arbeit und Soziales) (2016) Weißbuch. Arbeiten 4.0. Available from: http://www.bmas.de/DE/Service/Medien/Publikationen/a883-weissbuch.html. [Accessed 22 October 2017].

Brose, W. (2017) Von Bismarck zu Crowdwork: Über die Reichweite der Sozialversicherungspflicht in der digitalen Arbeitswelt. Neue Zeitschrift für Sozialrecht. 1, 7-14.

Bruckner, S. \& Krammer, C. (2017) Sozialversicherung in der Gig-Economy. In: Lutz D. \& Risak, M. (Hrsg.) Arbeit in der Gig-Economy. Wien, ÖGB Verlag, 254-302.

Buchiolz W. \& Wiegard W. (2014) Wie finanziert den deutschen Sozialstaat in Zukunft? Beiträge, Steurn and Privatisierung der Risiken. In: Masuch P. et al. Grundlagen und Herausforderungen des Sozialstaats. Denkschrift 60 Jahre Bundessozialgericht. Band I, Berlin, Erich Schmidt Verlag, $751-774$.

BuHr et al. (2017) Auf dem Weg zu Wohlfahrt 4.0? Die Digitalisierung des Wohlfahrtsstaates in den Politikfeldern Arbeit, Gesundheit und Innovation im europäischen Vergleich. Friedrich Ebert Stiftung. Available from: http://library.fes.de/pdf-files/id/13009.pdf. [Accessed 22 October 2017].

Bundestag (2014) Gutachten der wissenschaftlichen Dienste 'Rechtsfragen zum Crowdsourcing'. Available from: https://www.bundestag.de/blob/406942/2aaf68d8454b9ac2accf79818b4b9809/ wd-6-156-14-pdf-data.pdf [Accessed 22 October 2017].

Cherry, M. \& Aloisi, A. (2017) 'Dependent Contractors' in the Gig Economy: A Comparative Approach, American University Law Review, Vol. 66, Iss. 3, 635-689. Available from: http://digitalcommons.wcl.american.edu/aulr/vol66/iss3/1.

DAvidov, G. (2017) The Status of Uber Drivers: A Purposive Approach. Spanish Labour Law and Employment Relations Journal. Vol. 1-2, 6-15.

DÄUBLER, W. (2015) Internet und Arbeitsrecht. Frankfurt am Main, Bund Verlag.

De Stefano, V. (2016) The rise of the 'just-in-time workforce': On-demand work, crowdwork and labour protection in the 'gig-economy'. ILO. Conditions of work and employment, Series Nr.71, 
http://www.ilo.org/wcmsp5/groups/public/---ed_protect/---protrav/---travai1/documents/publication/wcms_443267.pdf. [accessed 21 October 2017].

DJT (2010) 68. Deutscher Juristentag, Beschlüsse zum Arbeits- und Sozialrecht, Available from: http:// www.djt.de/fileadmin/downloads/68/68_djt_beschluesse.pdf. [Accessed 22 October 2017].

DJT (2017) 71. Deutscher Juristentag, Beschlüsse zum Arbeits- und Sozialrecht, Available from: http://www. djt.de/fileadmin/downloads/71/161213_71_beschluesse_web.pdf. [Accessed 22 October 2017].

DrahoKoupiL, J. \& FABO, B. (2016). The platform economy and the disruption of the employment relationship. ETUI Policy Brief 5/2016. http://www.etui.org/Publications2/Policy-Briefs/EuropeanEconomic-Employment-and-Social-Policy/The-platform-economy-and-the-disruption-of-theemployment-relationship.

Egorova, K. (2017) Informal economy in Russia grows to record levels. Available from: https://www. rbth.com/business/2017/05/01/informal-economy-in-russia-grows-to-record-levels_751891 [Accessed 22 October 2017].

EuROFOUND (2015) Crowd employment. European Observatory of Working Life. Available from: https:// www.eurofound.europa.eu/observatories/eurwork/industrial-relations-dictionary/crowd-employment [Accessed 21 October 2017].

EuROPEAN COMmission (2018) Proposal for a Council recommendation on access to social protection for workers and the self-employed. Strasbourg, 13.3.2018, COM (2018)132 final.

FaljaHov, R. (2016) The staying power of an entrepreneur is short. Available from: https://www.gazeta. $\mathrm{ru} /$ business/2016/10/25/10269785.shtml [Accessed 22 October 2017].

Federal Ministry of Labour and Social Affairs (2015) Green Paper 4.0. Available from: http://www. bmas.de/EN/Services/Publications/arbeiten-4-0-greenpaper-work-4-0.html;jsessionid=2655889 FEE6257054E77CBF339A9612B [Accessed 22 October 2017].

FinkIN, M. W. (2016) Beclouded Work In Historical Perspective. Comparative Labour Law and Policy Journal, 37, 603-618.

Greiner, S. (2016) Die Vielfalt moderner Arbeitsformen im Sozialrecht. Die Sozialgerichtsbarkeit. 6, 301-309.

Hanau, P. (2017) Arbeits- und Sozialversicherungsrecht 4.0 im Weißbuch des BMAS. Recht der Arbeit, 213-216.

HARRIS, S. \& KRUEGer, A. (2015) A proposal for modernizing labor laws for twenty-first-century work: the "independent worker", The Hamilton Project, Discussion Paper 10, Available from: http:// www.hamiltonproject.org/assets/files/modernizing_labor_laws_for_twenty_first_century_work_ krueger_harris.pdf.

Huws, U.; SPenCER, N. \& Joyce, S. (2016) Crowd work in Europe. Preliminary results from a survey in the UK, Sweden, Germany, Austria and the Netherlands. University of Hertfordshire. Available from: http://researchprofiles.herts.ac.uk/portal/files/10749125/crowd_work_in_europe_draft_report_last_version.pdf [accessed 21 October 2017].

Interview ver.di und IG Metall (2016) 'Standards müssen her!'. Fragen der Redaktion. Arbeitsrecht im Betrieb. 7-8, 25-26.

IG Metall (2017) Die IG Metall ist auf der Höhe der Zeit. Available from: https://www.igmetall.de/ crowdworking-studie-des-hugo-sinzheimer-institut-hsi-25481.htm [accessed 21 October 2017].

Koalitionsvertrag zwischen CDU, CSU und SPD (2018) Ein neuer Aufbruch für Europa Eine neue Dynamik für Deutschland Ein neuer Zusammenhalt für unser Land. 19. Legislaturperiode. Available from: https://www.bundestag.de/blob/543200/9f9f21a92a618c77aa330f00ed21e308/kw49_koalition_koalitionsvertrag-data.pdf.

Kocher, E. \& Hensel, I. (2016) Herausforderungen des Arbeitsrechts durch digitale Plattformen - ein neuer Koordinationsmodus von Erwerbsarbeit. Neue Zeitschrift für Arbeitsrecht. 16, 984-990.

KRAUSE, R. (2016) Digitalisierung der Arbeitswelt - Herausforderungen und Regelungsbedarf. Band I: Gutachten / Teil B. Verhandlungen des 71. Deutschen Juristentages. Essen, C.H. Beck.

Leimeister, J.M. Durward D. \& Zogaj S. (2016) Crowd worker in Deutschland. Eine empirische Studie zum Arbeitsumfeld auf externen Crowdsourcing-Plattformen. Study 323. Hans Böckler Stiftung. Available from: https://www.boeckler.de/pdf/p_study_hbs_323.pdf. [Accessed 22 October 2017]. 
Lingemann, S.; von Steinau-Steinrück, R. \& Mengel, A. (2016) Employment \& Labor Law in Germany, Munich, Beck Verlag.

Ludwig, K. (2016) Crowdworking: Zum Leben reicht es kaum. Süddeutsche Zeitung. 24 August. Available from: http://www.sueddeutsche.de/digital/studie-crowdworking-zum-leben-reicht-eskaum-1.3134250 [Accessed 22 October 2017].

Lyutov, N. \& Gerasimova, E. (2017) The concept of employee: the position in Russia. In: Waas, B. \& van Voss, G.H. Restatement of Labour Law in Europe. Volume I. The Concept of Employee, Oxford and Portland, Oregon, Hart Publishing, 577-598.

Mecke, C. (2016) Arbeit 4.0. - Schöne neue sozialversicherungsfrei Arbeitswelt? Die Sozialgerichtsbarkeit. 9, 481-488.

Polorotov, A. (2017) 41\% of office workers note an increase in the number of freelancers in Russia. Available from: https://www.vedomosti.ru/management/articles/2017/05/25/691419-rost-frilanserov [Accessed 22 October 2017].

Preis, U. \& Brose, W. (2017) Sozialversicherungsrechtliche Einordnung neuer Beschäftigungsformen mit Schwerpunkt Plattform- bzw. Gig-Ökonomie. Bundesministerium für Arbeit und Soziales. Forschungsbericht 490. Available from: http://www.bmas.de/SharedDocs/Downloads/DE/PDFPublikationen/Forschungsberichte/fb-490-sozialversicherungsrechtliche-einordnung-neuer-beschaeftigungsformen-mit-schwerpunkt-plattform-bigoekonomie.pdf;jsessionid=7A799E953A401 B82D459631AD52EF283? _blob=publicationFile\&v=2 [accessed 1 June 2018].

Shevchuk, A. \& Strebkov D. (2017) Entrepreneurial Potential in the Digital Freelance Economy: Evidence from the Russian-Language Internet. In: Sauka, A. \& Chepurenko, A. (eds.) Entrepreneurship in Transition Economies, Springer International Publishing, 401-417.

Selzer, D. (2015) Crowdworking - Arbeitsrecht zwischen Theorie und Praxis. In: Husemann, T. \& Wietfeld, A. (Hrsg.) Zwischen Theorie und Praxis - Herausforderungen des Arbeitsrechts. Dokumentation der 5. Assistententagung im Arbeitsrecht vom 16. - 17.07.2015, Bochum 2015. BadenBaden, Nomos, 27-48.

SuÁrEz, C. (2017) The gig economy and its impact on social security: the Spanish example. EJSS, 293312 .

Suvorova, N. Time of freelancers: how new services change the labor market. Available from: http:// www.rbc.ru/magazine/2016/04/56ead0539a79474e4031fc91 [Accessed 22 October 2017].

Tornau, J. F. (2016) Im rechtsfreien Raum. Mitbestimmung. Das Magazin der Hans-Böckler-Stiftung. 2, 25-26. Available from: https://www.boeckler.de/cps/rde/xchg/hbs/hs.xsl/64540_64700.htm [Accessed 22 October 2017].

WALTERMAnN, R. (2010 a) Welche arbeits- und sozialrechtlichen Regelungen empfehlen sich im Hinblick auf die Zunahme Kleiner Selbständigkeit? Recht der Arbeit, 162-170.

Waltermann, R. (2010 b) Wesentliche Aussagen des Gutachtens zur Abteilung Arbeits- und Sozialrecht des 68. Deutschen Juristentages. Neue Zeitschrift für Arbeitsrecht. 860-865.

WaAs, B. (2017) Summary. In: Bernd Waas, B.; Liebman W.; Lyubarsky A. \& Katsutoshi K. (Hrsg.) Crowdwork. A Comparative Law Perspective. Frankfurt a. M., Bund-Verlag, 256-269. 